Proc. Estonian Acad. Sci. Biol. Ecol., 2004, 53, 3, 194-207

\title{
Health concerns in the Baltic States, Nordic countries, and Russia
}

\author{
Ott Roots $^{\mathrm{a}^{*}}$ and Vladimir Zitko ${ }^{\mathrm{b}}$ \\ ${ }^{a}$ Estonian Environment Research Centre, Marja 4D, 10617 Tallinn, Estonia \\ ${ }^{\mathrm{b}}$ Consultant, 114 Reed Ave, St. Andrews, NB, E5B 1A1, Canada \\ Received 22 January 2004, in revised form 5 April 2004

\begin{abstract}
Principal Component Analysis (PCA) of cancer incidences may indicate interesting differences among the Baltic States, Nordic countries, and Russia. For females the difference between Estonia, Latvia and Russia, and also between Finland and Iceland are likely caused by different incidences of lymphoid leukemia in these countries. In contrast to the incidence of cancer in females, the incidence of many different cancers contributes to the differences between 'west' and 'east' for cancers in males. It remains to be seen whether the suggestions indicated by the PCA could be substantiated and related to some environmental or sociological factors.
\end{abstract}

Key words: cancer, Baltic States, Nordic countries, Russia, PCDD, PCDF.

\section{INTRODUCTION}

Regarding mortality registration, there are substantial differences between the Nordic and the Baltic countries. This must be taken into account when comparing causes of death in the Nordic and the Baltic countries (Nordic/Baltic Health Statistics 1999, 2000).

In Estonia women tend to have a considerably longer life expectancy than men. In 1989-1997, the difference between female and male life expectancy increased from 9 to 11.3 years. It can be pointed out that during the post-war period the life expectancy of women has never been as long as during the last two years (Statistical Yearbook of Estonia, 1998; Roots, 1999, 2000).

The most important change for men as well as women in Estonia, both in incidence and in mortality, was the substantial decrease in stomach cancer rate (36\% decrease in incidence) from 1968 to 1992 . However, this decreasing trend was accompanied by an increased incidence of common cancers, such as lung cancer (40-50\% for both sexes) and female breast cancer (incidence by more than 50\%; Thomson et al., 1996). From 1968-1972 to 1988-1992 overall cancer mortality increased by $18 \%$ for males, but it was stable among females (Thomson et al., 1996).

*Corresponding author, ott.roots@klab.ee 
There are no data from the eastern part of the Baltic Sea about polychlorinated dibenzo-p-dioxins (PCDDs) and polychlorinated dibenzofurans (PCDFs) in food. The two (PCDD/Fs) are a group of toxic and persistent chemicals whose effect on human health and on the environment includes dermal toxicity, immunotoxicity, reproductive effects, teratogenicity, endocrine disrupting effects, and carcinogenicity. The most toxic PCDD/F isomers are those with chlorine substitution in the positions 2,3,7, and 8, comprising only 7 isomers among the 75 PCDDs, and 10 among the 135 PCDFs. In 1997 the International Agency for Research on Cancer, Lyon, classified the most toxic congener of the PCDD/Fs (2,3,7,8-TCDD) as a Group 1 compound, carcinogenic to humans (Dioxins and Furans Inventories, 1999). Recently, an increased risk of low birth weights in infants has been associated with a high consumption of contaminated fish from the Baltic Sea by their mothers (Rylander et al., 1995). Also, breast cancer incidents were higher than expected in women from the Baltic coast. These women consumed locally caught fatty fish at least twice as often as the control group (Rylander \& Hagmar, 1995). The Baltic Sea fish have been separately highlighted because in them the PCDD/F content presumably exceeds the threshold. There are large regional differences in the observed levels (Fig. 1).

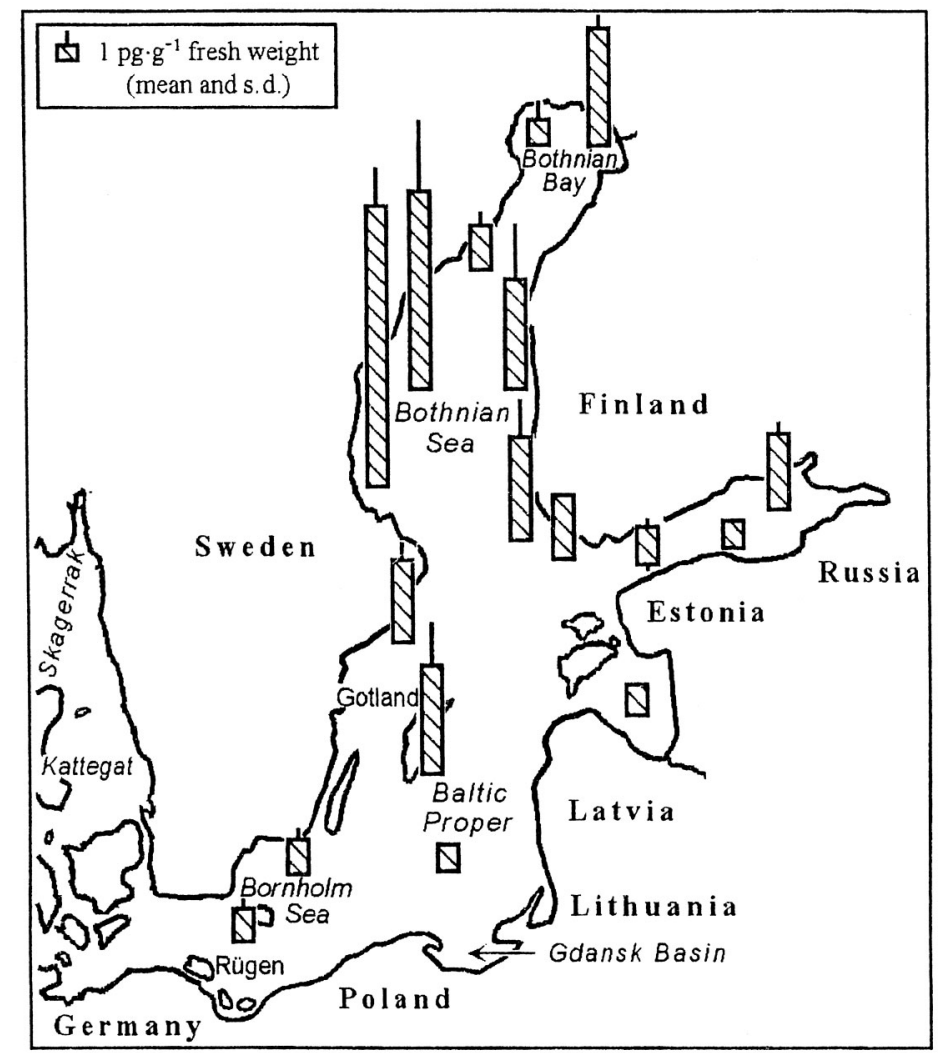

Fig. 1. Polychlorinated dibenzo-p-dioxins and polychlorinated dibenzofurans (PCDD/Fs) summary concentrations in the Baltic herring (HELCOM, 2003; Roots et al., 2003). 
Halogenated organic contaminants, released into marine ecosystems, are of great concern because of their toxicity, persistence, bioaccumulation through the food chain, and the public health aspects, such as consumption of fish. EU Council Regulation 2375/2001 put the threshold limit value of PCDD/Fs in fish at $4 \mathrm{pgTEQ} / \mathrm{g}$ wet weight. In the Finnish human intake of persistent organic pollutants (POPs), fish and fish products accounted for $82 \%$, and Baltic herring (Clupea harengus) alone for 52\% of the total intake (Kiviranta et al., 2001).

\section{METHODS AND MATERIALS \\ Principal component analysis of cancer rate incidences}

Cancer rate incidences were evaluated by Principal Component Analysis (PCA, see for example Zitko, 1994) of centred (mean $=0)$ and scaled $($ std $=1)$ profiles. The calculations were performed by PLS_Toolbox 2 (Wise \& Gallagher, 1998), running in Matlab 5.0 (The MathWorks Inc., Natick, MA 01760, USA). Graphs were prepared in Excel (Microsoft) and points were labeled by Labeler2 (Billo, 2001).

Three datasets were used:

1. Cancer rates of women as given in (Thomson, 1994; Roots, 2000), a 24 by 8 matrix;

2. Cancer rates of men as given in (Thomson, 1994; Roots, 2000), a 24 by 8 matrix;

3. Combined common cancers of women and men, a 17 by 16 matrix.

The sets 1-3 are labelled by the symbols $b s f a, b s m a$, and baltmfa, respectively, on the axes of Figs. 2-13. The fractions of the original variance captured by the principal components are indicated in the titles of the axes.

For PCA, the matrices were transposed, to treat the countries as objects (samples) and the cancers as variables.

In the PCA projections of cancer incidences (score plots), the countries are identified by their first letters in the sets 1 and 2 (Figs. 2, 3 and 6, 7). Numbers are used for the set 3 (see below, 1-8 women, 9-16 men, in the 8 countries, respectively):

$\begin{array}{lcl}\text { Females } & \text { Males } & \text { Country } \\ 1 & 9 & \text { Estonia } \\ 2 & 10 & \text { Latvia } \\ 3 & 11 & \text { Russia } \\ 4 & 12 & \text { Finland } \\ 5 & 13 & \text { Sweden } \\ 6 & 14 & \text { Norway } \\ 7 & 15 & \text { Denmark } \\ 8 & 16 & \text { Iceland }\end{array}$

The cancer type codes in the loading plots (Figs. 4, 5; 8, 9; and 12,13) are presented in Table 1. 
Table 1. Cancer type codes

\begin{tabular}{|c|c|c|c|c|c|}
\hline \multicolumn{2}{|l|}{ All cancers } & \multicolumn{2}{|l|}{ Female cancers } & \multicolumn{2}{|l|}{ Male cancers } \\
\hline All female \& male & A & All female & A & All male & A \\
\hline Bladder & $\mathrm{B}$ & Bladder & B & Bladder & B \\
\hline Colon & $\mathrm{C}$ & Colon & $\mathrm{C}$ & Colon & $\mathrm{C}$ \\
\hline Connective tissue & $\mathrm{Ct}$ & Connective tissue & $\mathrm{Ct}$ & Connective tissue & $\mathrm{Ct}$ \\
\hline Hodgkin's disease & $\mathrm{H}$ & Hodgkin's disease & $\mathrm{H}$ & Hodgkin's disease & $\mathrm{H}$ \\
\hline Kidney & $\mathrm{K}$ & Kidney & $\mathrm{K}$ & Kidney & $\mathrm{K}$ \\
\hline Liver & $\mathrm{L}$ & Liver & $\mathrm{L}$ & Liver & $\mathrm{L}$ \\
\hline Lung & $\mathrm{Lu}$ & Lung & $\mathrm{Lu}$ & Lung & $\mathrm{Lu}$ \\
\hline Lymphoid leukemia & Ly & Lymphoid leukemia & Ly & Lymphoid leukemia & Ly \\
\hline Melanoma & M & Melanoma & M & Melanoma & M \\
\hline In crowds of melanoma & $\mathrm{Mc}$ & In crowds of melanoma & $\mathrm{Mc}$ & In crowds of melanoma & $\mathrm{Mc}$ \\
\hline Myeloid leukemia & My & Myeloid leukemia & My & Myeloid leukemia & My \\
\hline Non-Hodgkin's lymphoma & $\mathrm{N}$ & Non-Hodgkin's lymphoma & $\mathrm{N}$ & Non-Hodgkin's lymphoma & $\mathrm{N}$ \\
\hline Oesophagus & $\mathrm{O}$ & Oesophagus & $\mathrm{O}$ & Oesophagus & $\mathrm{O}$ \\
\hline Pancreas & $\mathrm{P}$ & Pancreas & $\mathrm{P}$ & Pancreas & $\mathrm{P}$ \\
\hline Rectum & $\mathrm{R}$ & Rectum & $\mathrm{R}$ & Rectum & $\mathrm{R}$ \\
\hline Stomach & $\mathrm{S}$ & Stomach & $\mathrm{S}$ & Stomach & $S$ \\
\hline & & Cervix & $\mathrm{X}$ & Larynx & $\mathrm{Lx}$ \\
\hline & & Corpus uteri & $\mathrm{U}$ & Lip & $\mathrm{Li}$ \\
\hline & & Eye & $\mathrm{E}$ & Mouth & $\mathrm{M}$ \\
\hline & & Breast & B & Mouth laryx & $\mathrm{Mx}$ \\
\hline & & Other genitals & G & Prostate & $\mathrm{P}$ \\
\hline & & Ovary & $\mathrm{Ov}$ & Testicle & $\mathrm{T}$ \\
\hline & & Thyroid & $\mathrm{T}$ & Throat & Th \\
\hline
\end{tabular}

\section{Sample preparation and analysis}

Because there are no facilities for the measurement of PCDD/Fs in Estonia, the analyses of the Baltic herring samples (Henkelmann et al., 1996) were performed at the Institute of Ecological Chemistry of the National Research Centre for Environment and Health in Neuherberg, Germany. The Centre has been accredited in Germany for the determination of PCDD/Fs (accreditation licence No. DAC-P-0141-01-00 valid through 21.11.2006).

\section{RESULTS AND DISCUSSION}

As regards mortality from cancer, it is highest for men up to the age 75 years in the Baltic States and for women up to the age of 55 years (Nordic/Baltic Health Statistics, 1999, 2000). Incidence rates of cancer in Estonia are lower than the European average. Estonia has similar site distribution of cancer to Latvia and 
several other countries of Eastern Europe. When we compared the incidence rates of cancer among 66 European population groups, Estonia ranked 47th for males and 51st for females; Latvia ranked 57th for males and 58th for females (Thomson, 1994).

\section{Cancer incidence rates}

\section{Cancer in females ( $b s f a)$}

In the score plots (Figs. 2, 3) proximity indicates similarity and, as one would expect, Estonia (E) and Latvia (L) are similar and differ from Russia (R). The principal component No. 1 ( $\mathrm{pc}-1)$ is related primarily to the number of cancers.

It is interesting to note that the position of Russia (R) relative to the positions of $\mathrm{E}$ and $\mathrm{L}$ changes considerably in the $\mathrm{pc} 1 \& \mathrm{pc} 3$ projection (compare Fig. 2 with Fig. 3). The main reason for this seems to be the low incidence of lymphoid leukemia (Ly) in Russia. The incidence of the lymphoid leukemia in women and men in Russia ranks 62nd and 55th, respectively, amongst 67 populations. Estonia and Latvia rank 5th and 5th, and 12th and 18th, respectively (Thomson, 1994). However, the incidence rates of stomach cancer and lymphocytic leukemia

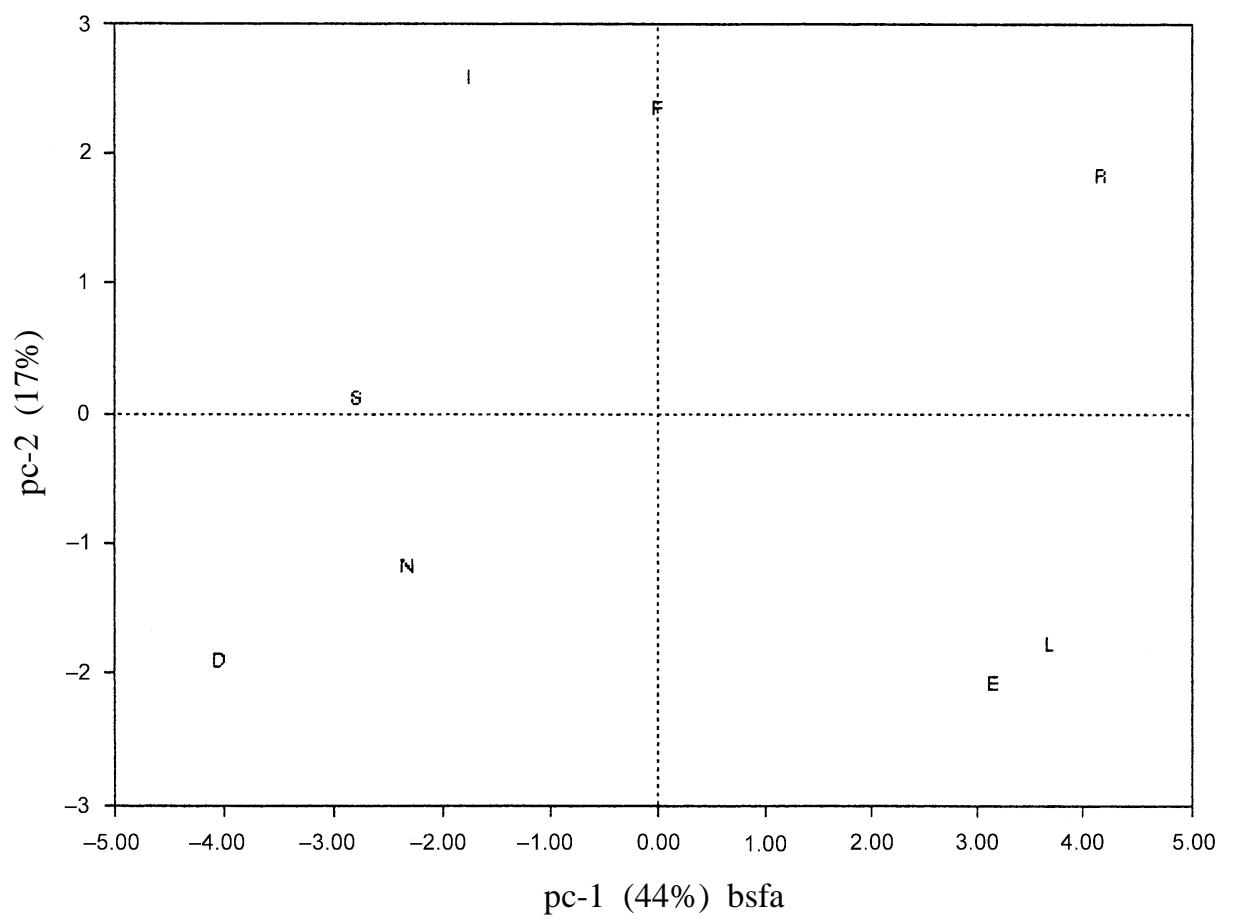

Fig. 2. A score plot of cancer incidences. 


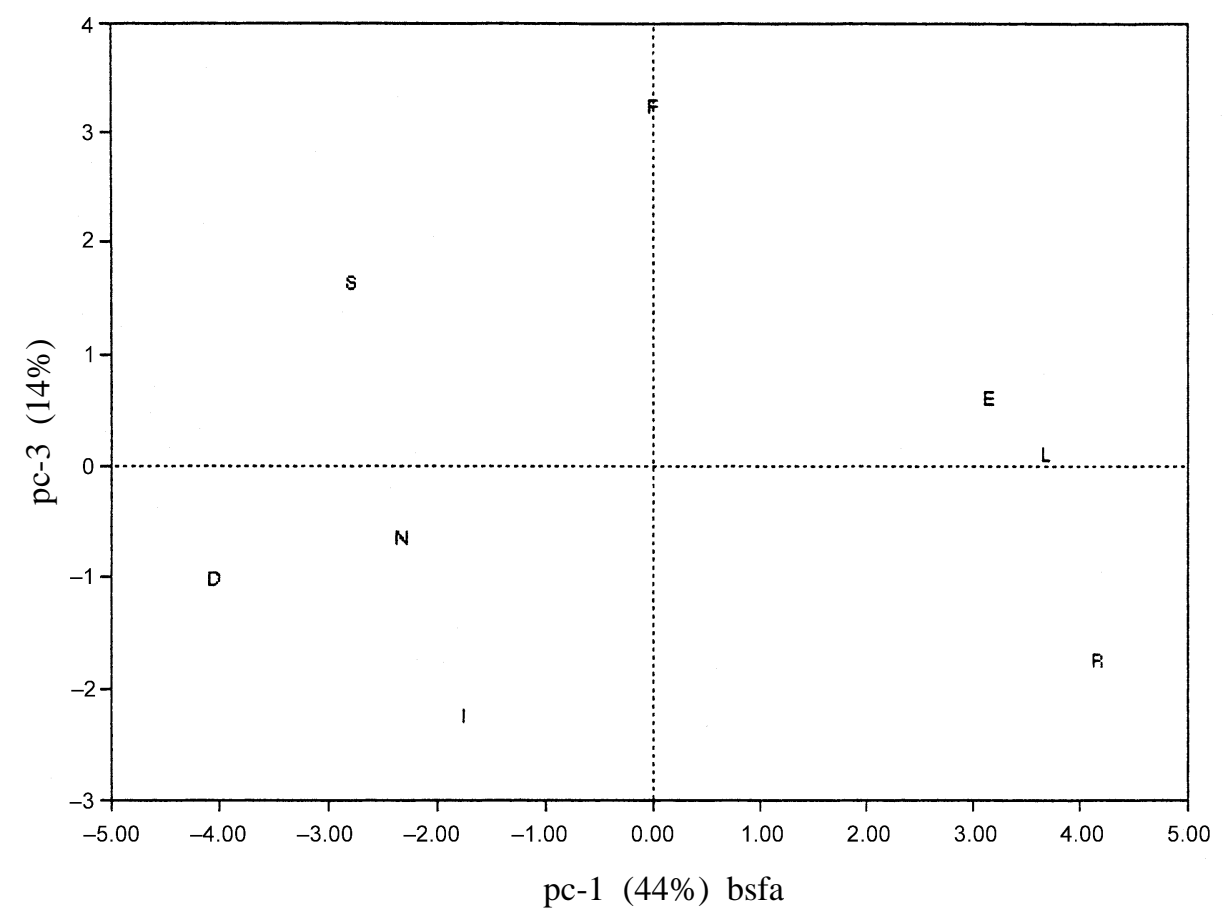

Fig. 3. A score plot of cancer incidences.

in both sexes and cancer of the pancreas in males were higher in Estonia than, on average, those in other European countries (Thomson, 1994; Thomson et al., 1996).

The reason for the change in the positions of $\mathrm{E}, \mathrm{L}$, and $\mathrm{R}$ can be seen from the 'loading' (eigenvector, ev) plots, which indicate the effects of the original variables (cancers) on the new coordinates, the principal components. The ev- $1 \&$ ev- 2 and ev-1 \& ev-3 plots are shown in Figs. 4 and 5. The change in the position of $\mathrm{R}$ must be due to a cancer that has a different effect on the pc-2 as opposed to its effect on the pc-3. When there are many variables, as in this case, the finding of single responsible variables may not be possible. However, in this case it seems that Ly is the variable whose effects on pc-2 (ev-2) and pc-3 (ev-3) are large and in opposite directions. Consequently, the difference between E, L, and R, and also between $\mathrm{F}$ and I, are likely caused by different incidences of lymphoid leukemia in these countries.

From the loading plots in Figs. 4 and 5 one can also see that the difference between $\mathrm{D}, \mathrm{N}, \mathrm{S}$, and $\mathrm{E}$, and $\mathrm{L}$ and $\mathrm{R}$ is caused by the different incidence of Hodgkin's disease $(\mathrm{H})$ and stomach cancer $(\mathrm{S})$, in the former countries. 


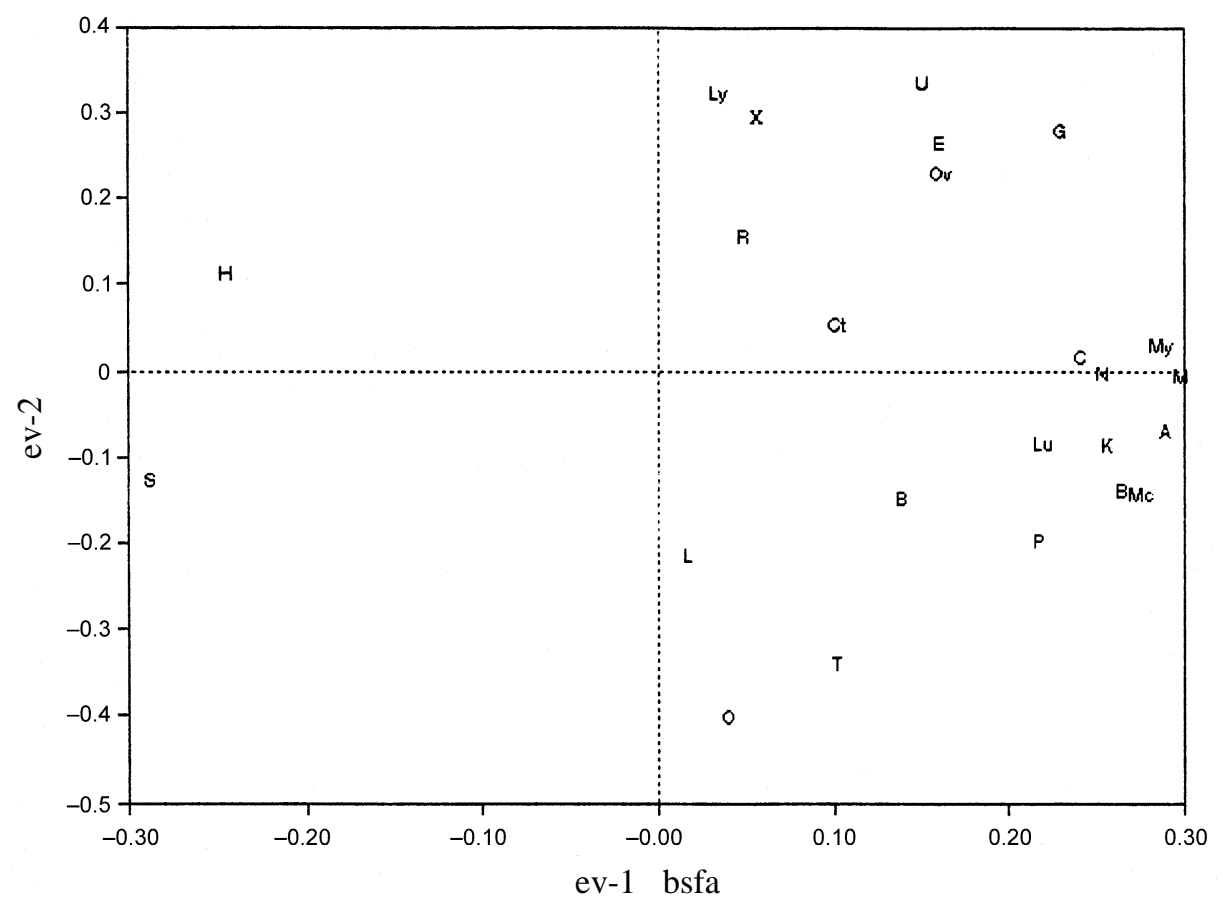

Fig. 4. Loading plot.

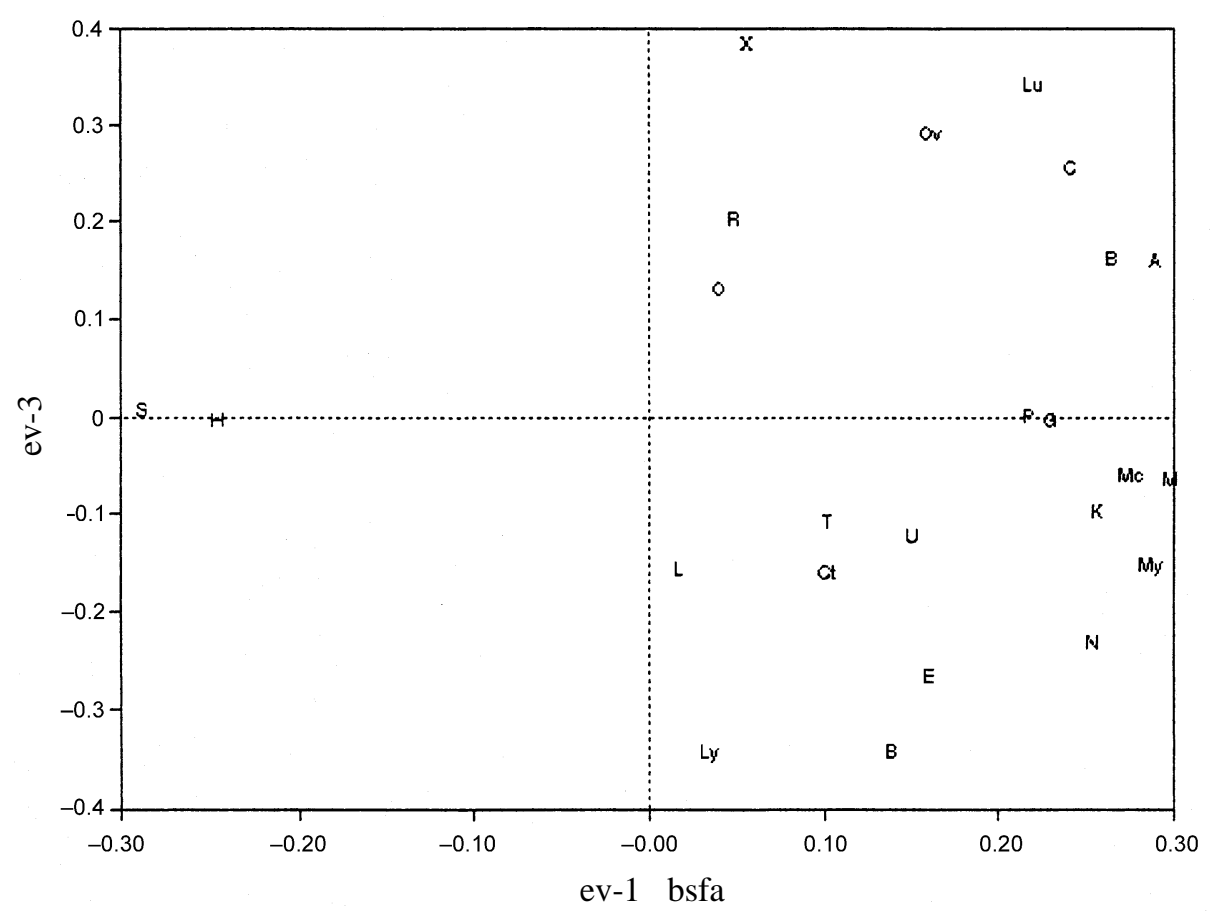

Fig. 5. Loading plot. 


\section{Cancers in males (bsma)}

A 'west to east' difference can be observed also in male cancers, but in this case there are large differences between Latvia, Estonia, and Russia as well, as can be seen from the score plots in Figs. 6 and 7. There are also differences between Sweden and Norway, and between Iceland and Finland.

The incidence of lip cancer ( $\mathrm{Li}$ ) may play a role in the difference between Russia and Latvia. As can be seen in Figs. 8 and 9, Li has a high weight on ev-2 and practically no effect on ev-3. The incidences of bladder (B) and colon (C) cancer may be responsible for the difference between Iceland and Finland and also between Sweden and Norway.

In contrast to the incidence of cancer in females, the incidence of many different cancers contributes to the differences between 'west' and 'east' for cancers in males (see loading plots, Figs. 8 and 9).

\section{Cancers in males and females (baltmfa)}

As can be seen from the score plots (Figs. 10 and 11), the differences in the cancer incidence rate profiles between males and females are relatively small in Estonia, Latvia, Russia, and Finland, and large in Sweden, Denmark, Norway, and Iceland.

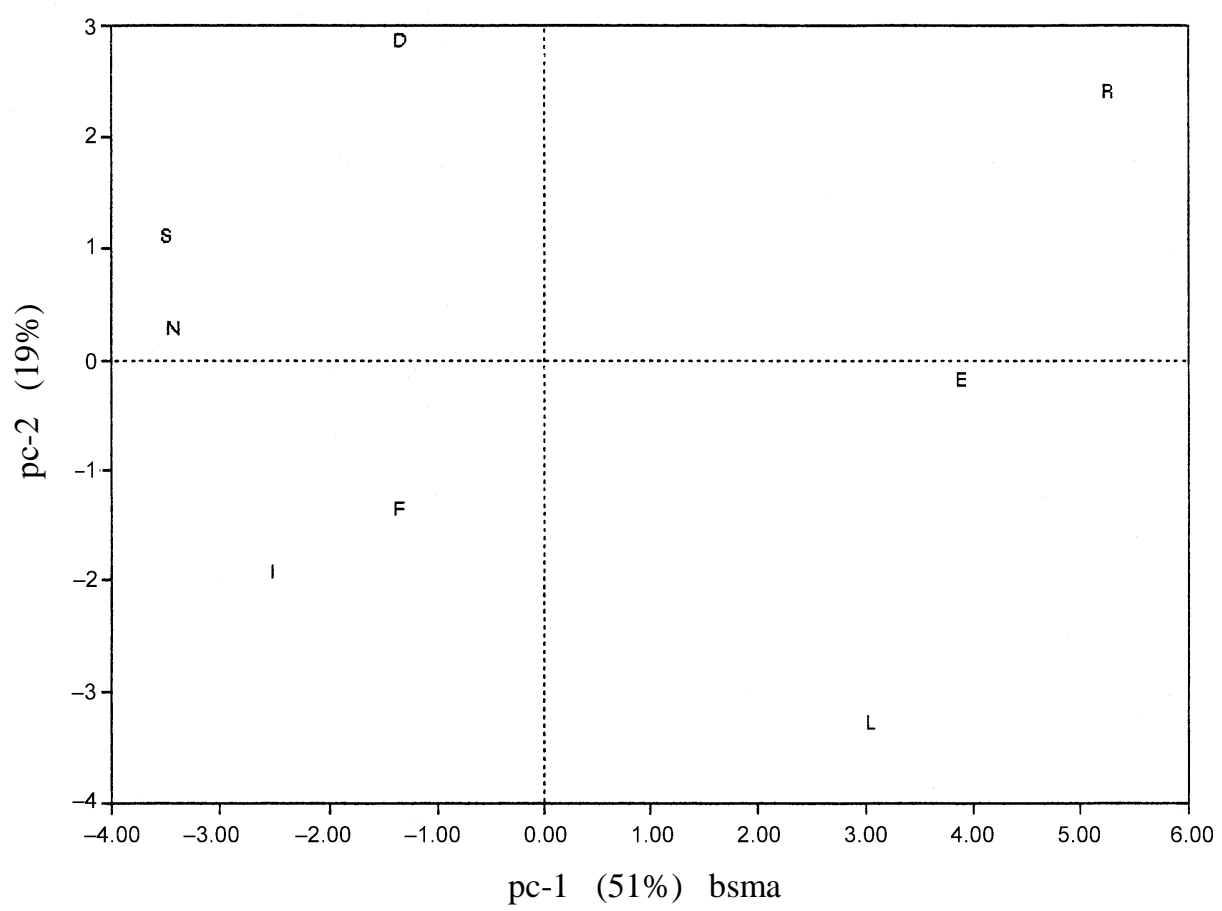

Fig. 6. A score plot of cancer incidences. 


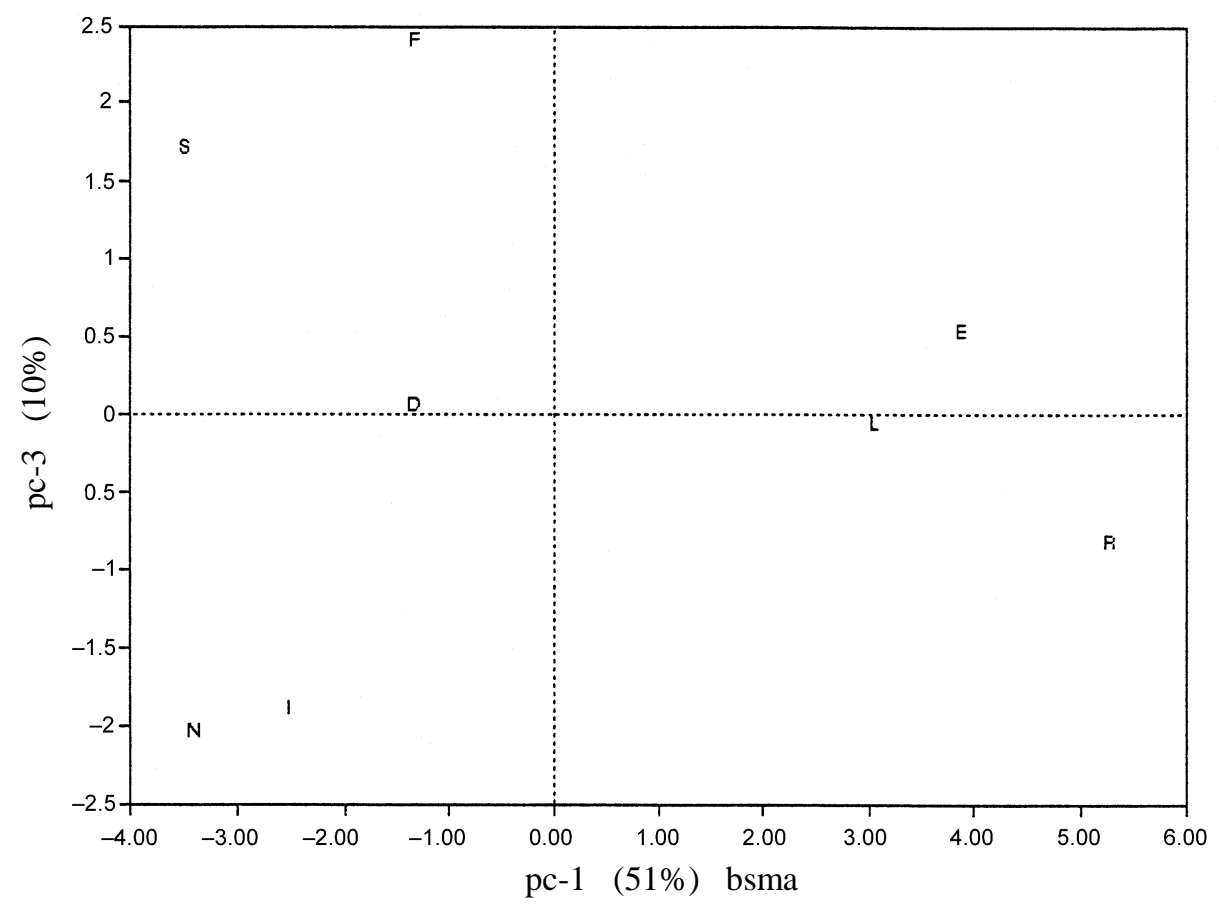

Fig. 7. A score plot of cancer incidences.

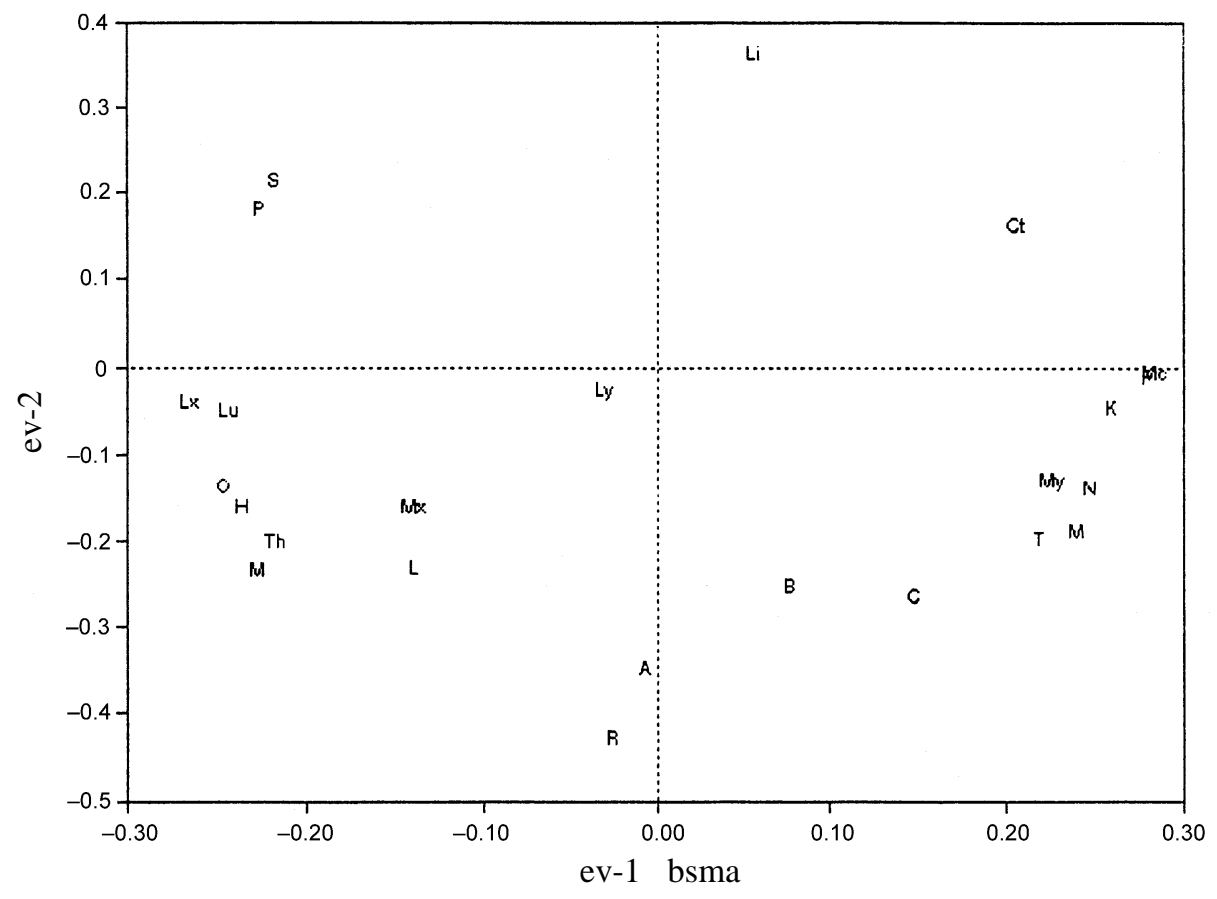

Fig. 8. Loading plot. 


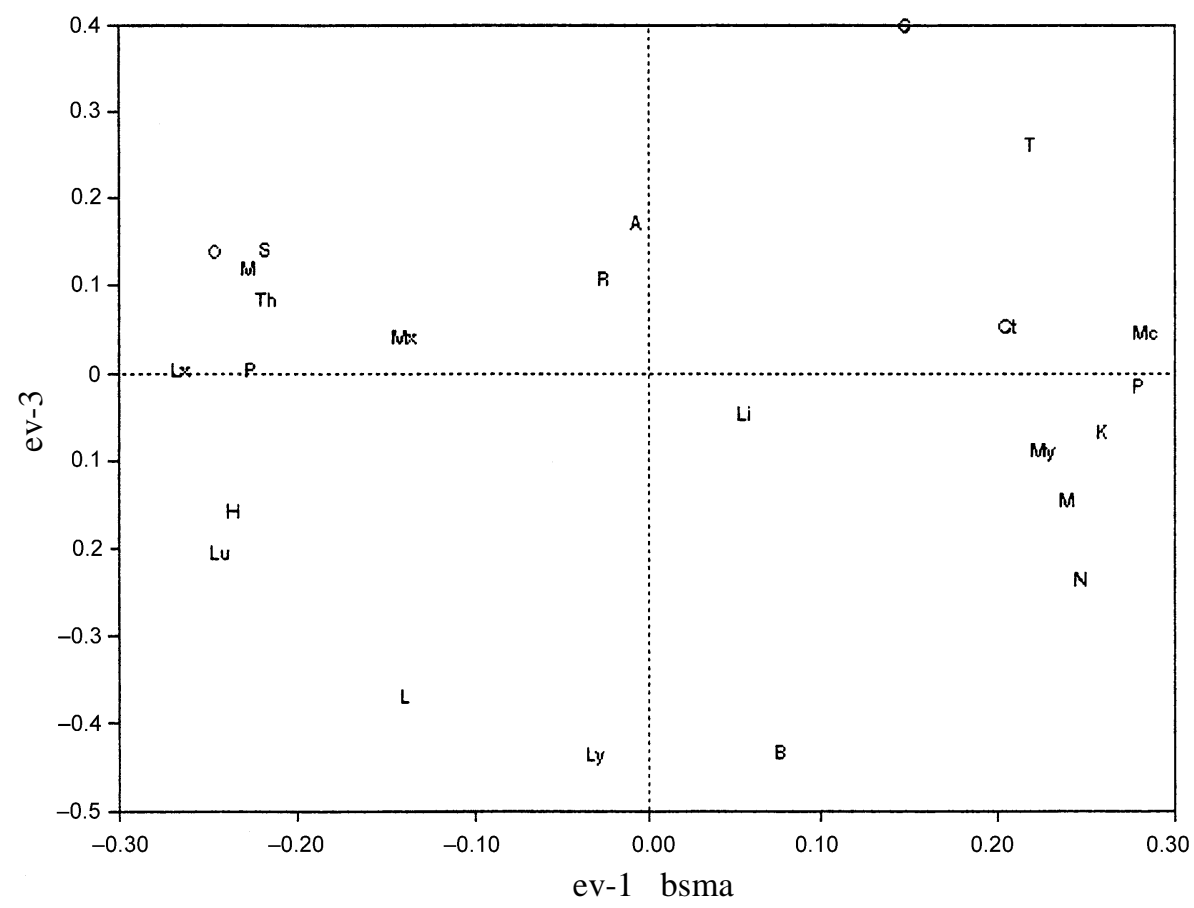

Fig. 9. Loading plot.

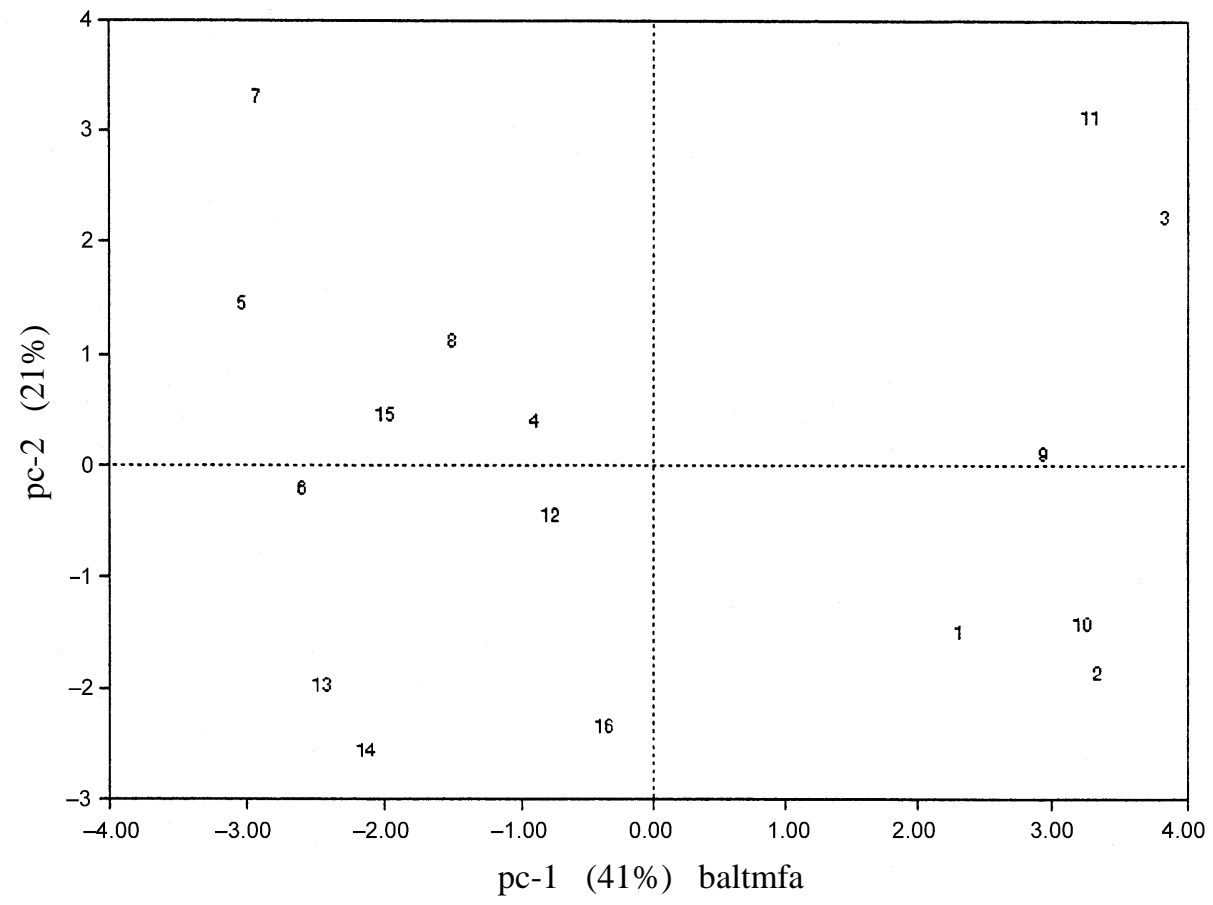

Fig. 10. A score plot of cancer incidences (see Methods). 


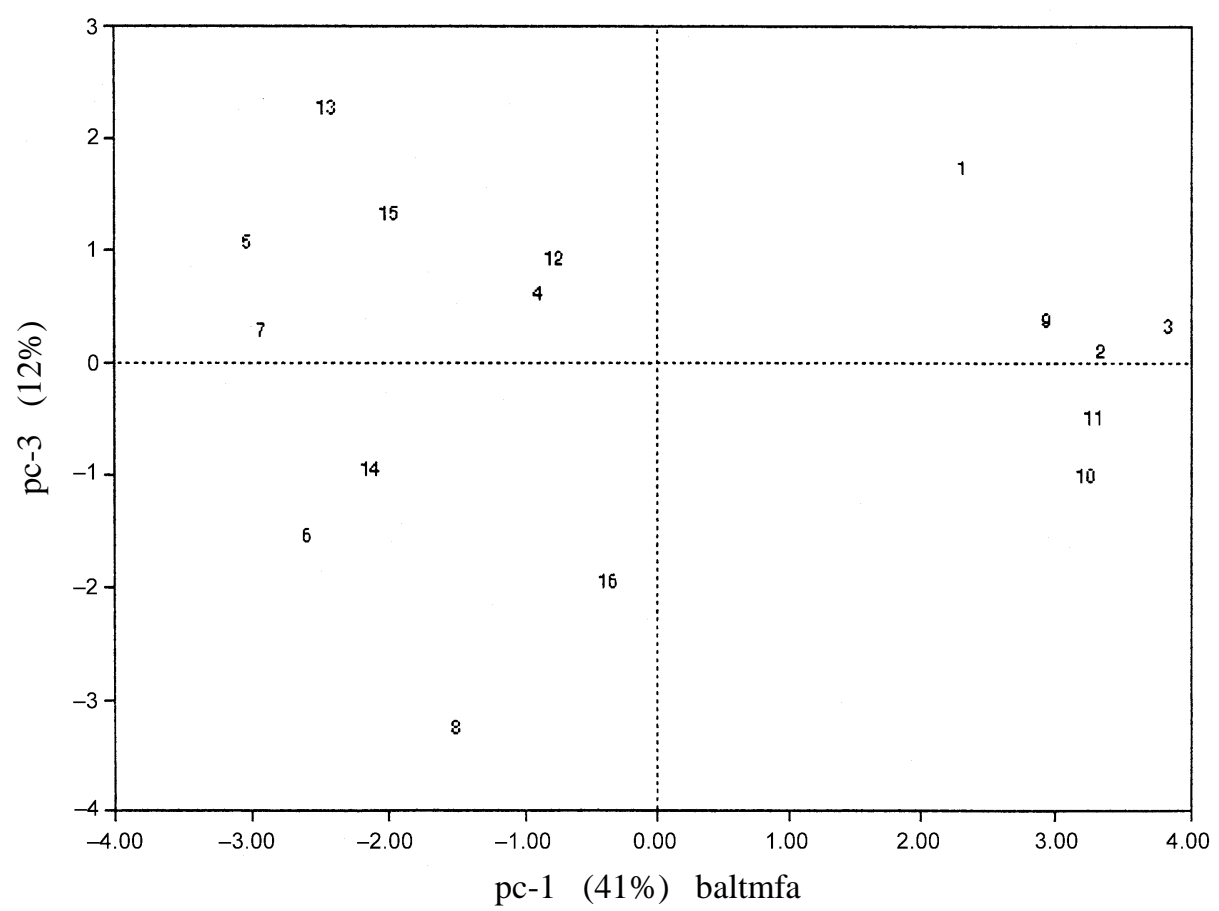

Fig. 11. A score plot of cancer incidences (see Methods).

When cancer incidence rates in females and males are considered together, it is again Hodgkin's disease and colon cancer that are responsible for the 'east/west' difference (loading plots, Figs. 12 and 13).

Baltic herring (Clupea harengus membras L.) is the most important fish species in the Baltic and for the Estonian fish processing industry. The Estonian estimated minimum food basket consisting of 41 foodstuffs has been put together by the Department of Public Health of the Ministry of Social Affairs and has been coordinated with dieticians (amounts of fish and fish preparations in the basket $2.4 \mathrm{~kg}$ per person in a month) (Statistical Office of Estonia, 2002). Consequently, the presence of toxicants in this species and in fish in general is of concern from the point of view of human health.

The time and place of catch, i.e. the population location, play an important role when different regions are compared. Concentrations of chlorinated pesticides, polychlorinated biphenyls (PCBs), and PCDD/Fs in Baltic Sea herring vary regionally. After the highest DDT and $\mathrm{PCB}$ concentrations in the herring muscle tissue off the German coast (HELCOM, 2003) the second most PCDD/Fcontaminated fish are found off the eastern coast of Sweden in the Bothnian Sea (Fig. 1). 


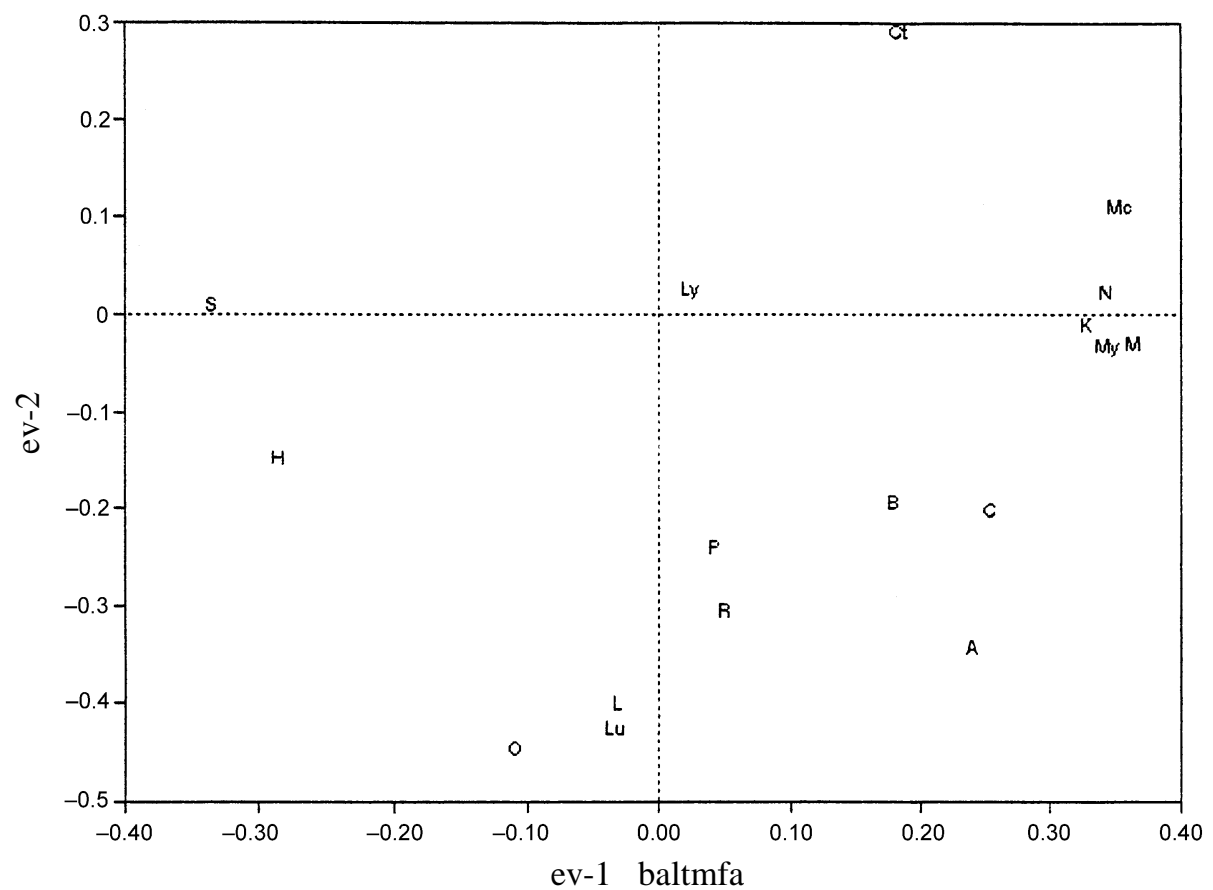

Fig. 12. Loading plot.

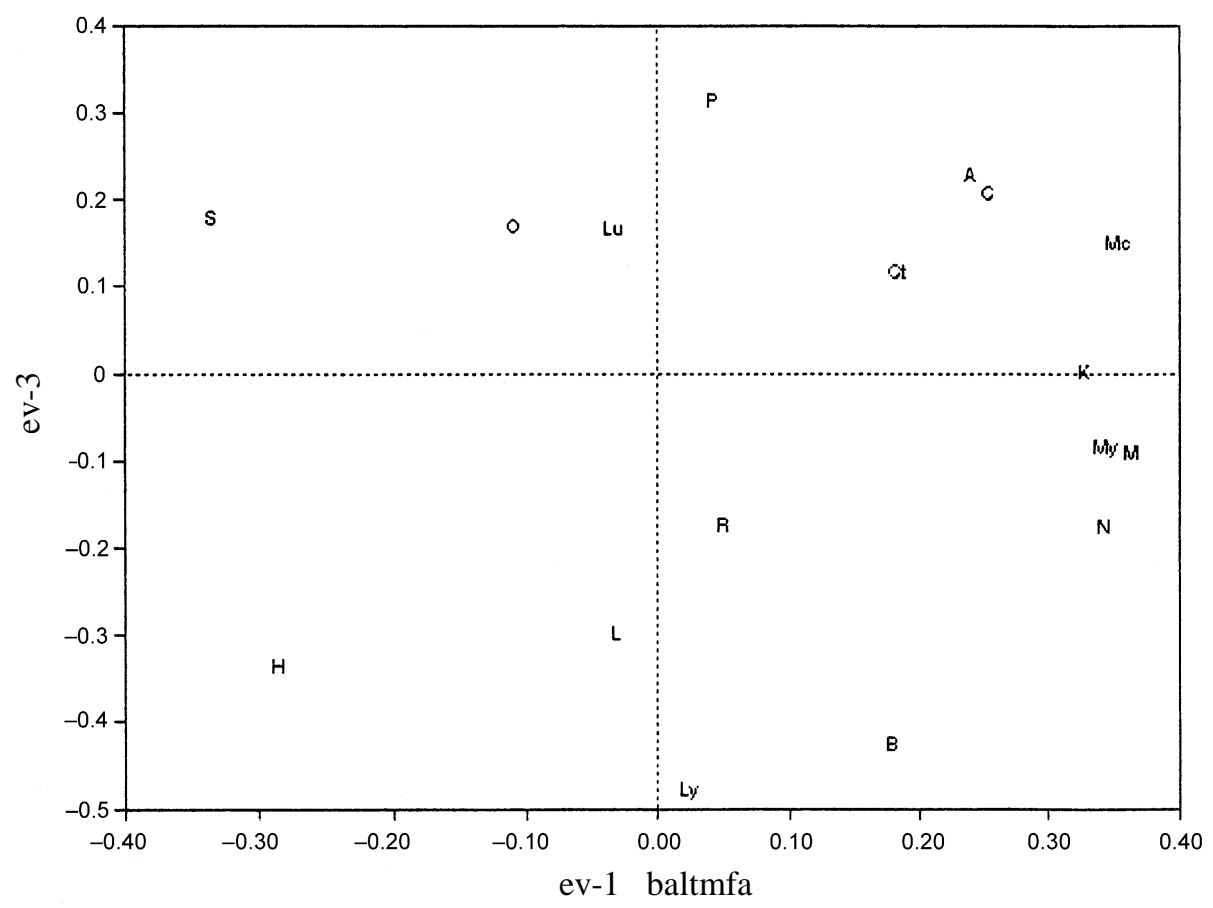

Fig. 13. Loading plot. 
The exposure of the average population in the East Baltic region (Estonia, Latvia, and Lithuania) to chlorinated compounds and the current use of pesticides are very low and seem to be lower than in most of Western Europe (Holoubek et al., 2000). However, local sites of concern exist (Agrell et al., 2001).

\section{CONCLUSIONS}

Principal component analysis of cancer incidences may indicate interesting differences among countries. It remains to be seen whether the suggestions indicated by PCA could be substantiated and related to some environmental or sociological factors. When cancer incidence rates in females and males are considered together, it is Hodgkin's disease and colon cancer that are responsible for the 'east/west' difference. For females the difference between Estonia, Latvia, and Russia, and also between Finland and Iceland are likely caused by different incidences of lymphoid leukemia in these countries. In contrast to the incidence of cancer in females, the incidence of many different cancers contributes to the differences between 'west' and 'east' for cancers in males.

The Baltic herring samples taken from four regions of Estonian coastal waters during spring 2002 were below the internationally permitted threshold. The results do not eliminate the need to monitor the toxicants in fish also in the future because the use of hazardous chemicals in the Baltic region will probably continue.

\section{ACKNOWLEDGEMENT}

The dioxin analyses in spring 2002 were financially supported by the Estonian Ministry of the Environment.

\section{REFERENCES}

Agrell, C., Larsson, P., Okla, L., Bremle, G., Johansson, N., Klavins, M., Roots, O. \& Zelechowska, A. 2001. Atmospheric and river input of PCBs, DDTs and HCHs to the Baltic Sea. In A System Analysis of the Baltic Sea (Wulff, F., Rahm, L. \& Larsson, P., eds.). Ecol. Stud., 148, 149-175.

Billo, E. J. 2001. Excel for Chemists. A Comprehensive Guide. Wiley-VCH, New York.

Dioxins and Furans Inventories. 1999. UNEP Chemicals.

HELCOM. 2003. The Baltic Sea Environment 1999-2002. Balt. Sea Env. Proc., 87, 24-31.

Henkelmann, B., Schramm, K. W., Klimm, C. \& Kettrup, A. 1996. Quality criteria for the isotope dilution method with HRGC/MS. Fresenius. J. Anal. Chem., 354, 818-822.

Holoubek, I., Kocan, A., Holoubkova, I., Hilscherova, K., Kohoutek, J., Falandysz, J. \& Roots, O. 2000. Persistent, bioaccumulative and toxic chemicals in the Central and Eastern European countries - state-of-the-art report. TOCOEN Report 150a.

Kiviranta, H., Hallikainen, A., Ovaskainen, M.-L., Kumpulainen, J. \& Vartiainen, T. 2001. Dietary intakes of PCDDs, PCDFs and PCBs in Finland. Food Addit. Contam., 18(11), 945-953.

Nordic/Baltic Health Statistics 1999. 2000. Nordic Medico-Statistical Committee, Copenhagen. 
Roots, O. 1999. The Effect of Environmental Pollution on Human Health in the Baltic States (Assessment and Regional Differences). Tallinn.

Roots, O. 2000. Health concerns in the Baltic countries and environmental quality. Ecol. Khim., 9, 64-72. Thesa, St. Petersburg (in Russian).

Roots, O., Lahne, R., Simm, M. \& Schramm, K.-W. 2003. Dioxins in the Baltic herring and sprat in Estonian coastal waters. Organohalogen Compounds, 62, 201-203.

Rylander, L. \& Hagmar, L. 1995. Mortality and cancer incidence among women with a high consumption of fatty fish contaminated with persistent organochlorine compounds. Scand. J. Work Environ. Health, 21, 419-426.

Rylander, L., Strömberg, U. \& Hagmar, L. 1995. Decreased birth weight among infants born to women with a high dietary intake of fish contaminated with persistent organochlorine compounds. Scand. J. Work Environ. Health, 21, 368-375.

Statistical Office of Estonia. 2002. Estimated subsistence minimum. Estonian Statistics, No. 1, 5-6. Statistical Yearbook of Estonia. 1998. Statistical Office of Estonia, Tallinn.

Thomson, H. 1994. Vähihaigestumus Eestis läbi Euroopa prisma. Eesti Arst, 5, 355-359.

Thomson, H., Rahu, M., Aarelaid, T. \& Gornoi, K. 1996. Cancer in Estonia 1968-1992. Incidence, Mortality, Prevalence, Survival. Institute of Experimental and Clinical Medicine, Tallinn.

Wise, B. M. \& Gallagher, N. B. 1998. PLS_Toolbox Version 2.0. Eigenvector Research, Inc., 830 Wapato Lake Road, Manson, WA 98831, USA.

Zitko, V. 1994. Principal component analysis in the evaluation of environmental data. Marine Pollut. Bull., 28, 718-722.

\title{
Balti riikide, Põhjamaade ja Venemaa elanikkonna tervise võrdlus
}

\author{
Ott Roots ja Vladimir Zitko
}

Kasutades vähkkasvajate esinemissageduse uurimisel analüüsipõhiste komponentide (APK) analüüsi meetodit, on Balti riikide, Põhjamaade ja Venemaa elanikkonna vahel esile toodud huvitavaid erinevusi. Kui, kasutades APK-meetodit, eeltoodud riikide vähkkasvajate esinemissagedust võrrelda meestel ja naistel koos, on nn ida-läänesuunaliste erinevuste põhjustajaks erinevus kahe vähivormi - käärsoolevähi ja Hodgkinsoni tõve - esinemissageduses. Naiste puhul põhjustab lümfiline leukeemia erinevust nii Eesti, Läti kui Venemaa, aga samuti Soome ja Islandi vähkkasvajate esinemissageduse vahel. Erinevalt naistest on meeste puhul nn ida-läänesuunaliste erinevuste põhjustajaks palju enam erinevaid vähkkasvajavorme.

Kuna üheks vähkkasvajate esinemise põhjustajaks Läänemere-äärsetes riikides peetakse dioksiine, siis analüüsiti nende ühendite sisaldust neljas Eesti rannikumere regioonis 2002. aasta kevadel püütud räimeproovides. Saadud andmeid võrreldi teiste Läänemere riikide vastavate näitajatega. Kõigis Eesti räimeproovides jäi dioksiinide sisaldus allapoole Euroopa Liidu poolt kehtestatud normist, mille puhul toksikantide hulk toidus ei tohiks haigusnähte esile kutsuda. 